\title{
NILAI PENGANTIN PEREMPUAN DALAM MAS KAWIN SUKU BANGGAI DITINJAU DARI KONSEP IMAGO DEI DALAM KEJADIAN 1:26-27
}

\author{
Yusdian Lumbon, Ermin Alperiana Mosooli, Oskar Sopang \\ Sekolah Tinggi Teologi Star's Lub Luwuk Banggai
}

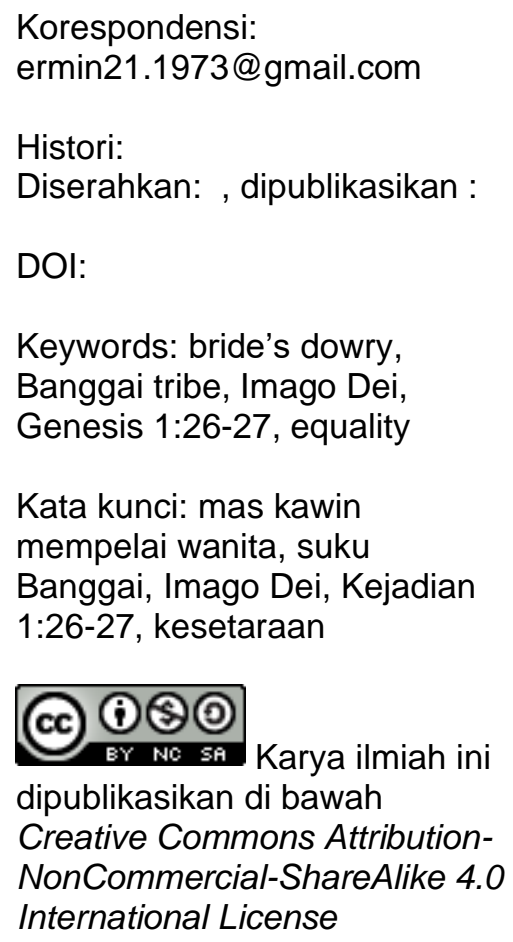

\begin{abstract}
This study aims to examine the bride's value in the Banggainese (in Central Sulawesi Province, Indonesia) dowry tradition from the concept of man and woman as Imago Dei in Genesis 1: 26-27. The method used is a literature study with content analysis as a data analysis technique. The results showed that the prospective bride's value in the Banggainese dowry tradition contradicts the human concept as Imago Dei in Gen 1: 26-27. As Imago Dei, women and men are created equal and are equally servants of Allah whose position is above other creations. The bride's value in the Banggainese dowry tradition shows that women's status is lower than men. It put a prospective bride as an object who could exchange for family prestige and adjusted with things like money.
\end{abstract}

Abstrak. Penelitian ini bertujuan meninjau nilai mempelai wanita dalam tradisi pemberian mas kawin pada adat pernikahan suku Banggai di Sulawesi Tengah dari sudut pandang konsep manusia, laki-laki dan perempuan, sebagai Imago Dei dalam Kejadian 1:26-27. Metode yang digunakan adalah studi pustaka dengan analisa isi (content analisys) sebagai teknik analisa data. Hasil penelitian menunjukkan bahwa nilai calon mempelai wanita dalam perkawinan adat suku Banggai bertentangan dengan konsep manusia sebagai Imago Dei dalam Kej 1:26-27. Manusia perempun dan laki-laki sebagai Imago Dei dalam Kej 1:2627 diciptakan setara dan sama-sama merupakan hamba Allah yang posisinya berada di atas ciptaan lainnya. Nilai mempelai wanita dalam tradisi pemberian mas kawin suku Banggai menunjukkan posisi perempuan yang lebih rendah dari laki-laki. Dalam penetapan nilai mempelai wanita, ia ditempatkan sebagai obyek yang nilainya ditukar dengan nilai prestise keluarga. Selain itu, nilai mempelai wanita disetarakan dengan benda berupa uang dan benda lainnya.

\section{PENDAHULUAN}

Tradisi pemberian mas kawin atau mahar dari calon mempelai lakilaki kepada calon mempelai wanita merupakan bagian penting dalam adat

(c) 2021 Yusdian Lumbon, Ermin Alperiana Mosooli, Oskar Sopang 
pernikahan masyarakat di Indonesia pada umumnya. Dalam Islam, mas kawin bahkan masuk dalam ranah agama. Menurut Basri, mas kawin merupakan sebuah kewajiban yang harus dipenuhi dalam Islam (Basri 2017).

Neonnub \& Habsari dalam penelitian mereka mengenai sejarah belis, mas kawin pada masyarakat Insana Kabupaten Timor Tengah Utara, menunjukkan bahwa belis merupakan suatu peninggalan kebudayaan dari leluhur yang diadopsi dari kehidupan para raja atau bangsawan yang pada intinya adalah "isteri ikut suami". Pada zaman dahulu jika seorang puteri raja menikah maka ia akan keluar dari kerajaannya dan berpindah pada kerajaan suaminya. Sang suami memberikan belis kepada keluarga sang puteri sebagai ucapan terima kasih dan penghargaan atas restu yang diberikan. Kebiasaan ini kemudian diikuti oleh para bangsawan dan rakyat biasa dan menjadi kebiasaan turun temurun (Neonnub dan Habsari 2018). Di kalangan masyarakat biasa, menurut Koentjaraningrat, pada awalnya mas kawin digunakan sebagai ganti rugi atas tenaga seorang gadis yang sangat dibutuhkan dalam suatu kelompok yang hilang diambil kelompok lain karena pernikahan (Bangngu 2015).

Bentuk dan jumlah mas kawin beragam di berbagai komunitas. Bahkan hasil penelitian Noryamin Aini tahun 2014 terhadap Tradisi Mahar Di Ranah Lokalitas Umat Islam menemukan bahwa pemberian mas kawin, baik bentuk dan jumlahnya, bergantung pada faktor sosial ekonomi 
komunitas setempat. Pada keluarga dengan status sosial yang tinggi, mas kawin biasanya dalam bentuk simbolik (misalnya jumlah uang berdasarkan angka tanggal pernikahan), termasuk simbol-simbol keagamaan (alat shalat, kitab suci, buku agama dan ritus keagamaan). Mas kawin dalam bentuk perhiasan dan uang kebanyakan diminta oleh keluarga dengan status sosial sedang atau rendah (Aini 2014).

Dari sini nampak bahwa mas kawin sebenarnya merepresentasikan nilai seorang calon mempelai wanita. Dalam ilmu sosiologi, menurut Helmut Thome, nilai memiliki dua pengertian. Pertama nilai dipahami sebagai "sesuatu yang dikenakan secara langsung atau dianggap melekat pada suatu obyek yang disukai". Kedua, nilai juga dipahami sebagai keyakinan atau konsepsi (abadi) yang menafsirkan sesuatu sebagai hal yang lebih disukai atau lebih diinginkan (Thome 2015). Berdasarkan pengertian ini maka dapat disimpulkan bahwa nilai merupakan sesuatu yang dianggap atau diyakini melekat pada suatu obyek. Dalam hal mas kawin, obyek tersebut adalah calon mempelai wanita. Sesuatu yang melekat pada dirinya itulah yang diukur dengan jumlah dan bentuk mas kawin. Ukuran tersebut didasarkan pada anggapan, keyakinan, atau penafsiran pihak-pihak yang menentukan bentuk dan jumlah mas kawin.

Pada umumnya bentuk dan jumlah mas kawin ditentukan dalam suatu musyawarah keluarga kedua belah pihak. Dalam musyawarah tersebut pihak keluarga calon mempelai wanita mengajukan bentuk dan jumlah mas kawin kepada pihak laki-laki. Jadi pihak keluarga calon 
mempelai wanita berperan penting dalam penentuan mas kawin (Alfida dan Usman 2016). Biasanya akan terjadi proses tawar menawar. Laki-laki mengajukan penawaran apabila menganggap jumlah yang diminta tidak sesuai kemampuannya (Ladjahia 2015). Dalam hal ini calon mempelai wanita ditempatkan sebagai obyek. Dia tidak dilibatkan dalam penetapan mas kawin. Orang lain yang menentukan nilai dirinya.

Beberapa riset menunjukkan bahwa dasar untuk menentukan jumlah mas kawin cenderung pada status sosial keluarga, khususnya keluarga calon mempelai wanita. Di masa lalu, status kebangsawanan keluarga calon mempelai wanita menentukan jumlah mas kawin. Di masa kini, tingkat pendidikan calon mempelai wanita menjadi salah satu patokan. Makin tinggi pendidikannya, makin tinggi jumlah mas kawin. (Ladjahia 2015). Jadi yang "disukai" oleh para penentu jumlah mas kawin yang dianggap melekat pada diri calon mempelai wanita sebenarnya adalah status sosialnya, termasuk status sosial keluarganya.

Dalam penelitian Ladjahia di suku Banggai, mas kawin cenderung diminta dalam bentuk uang tunai. Mas kawin tersebut terdiri atas dua bagian, yaitu bagian yang diberikan kepada orang tua mempelai wanita dan bagian (utama, terbanyak) untuk biaya pesta pernikahan. Hal ini berkaitan dengan prestise sosial keluarga. Makin tinggi jumlah mas kawin, makin meriah pesta pernikahan, makin naik status sosial keluarga (Ladjahia 2015). 
Meski demikian kenyataannya, tapi jumlah mas kawin cenderung disamakan dengan nilai calon mempelai wanita itu sendiri. Jika jumlah mas kawin tinggi berarti nilai calon mempelai wanita itu tinggi. Nilai ini kemudian dikonversi dalam bentuk benda, baik berupa barang atau uang tunai, yang tujuannya sebenarnya untuk memenuhi suatu kebutuhan di luar dirinya. Pertanyaan yang menarik untuk diajukan adalah apakah nilai mas kawin merendahkan atau mengagungkan calon mempelai wanita?

Dalam Islam, menurut Subhan, mas kawin atau mahar merupakan pemberian tanda cinta dan kasih sayang, tanda penghormatan kepada perempuan, dan lambang tanggung jawab untuk menafkahi istri. (Subhan 2018). Aprianti menegaskan mahar merupakan penghormatan terhadap kemanusiaan perempuan. Dalam Islam, mahar bukan harga seorang perempuan sehingga isteri bisa dimiliki seperti barang. (Apriyanti 2017). Mahar, seperti dikatakan Muh. Ali \& Azahari, bukanlah perdagangan perempuan, sebaliknya merupakan pemberian yang bertujuan melindungi perempuan, menunjukkan penghormatan, penghargaan dan kemuliaan kepada para perempuan (Muh. Ali dan Azahari 2013).

Dalam Kristen, sepertinya mas kawin belum menjadi bagian dari ajaran gereja atau diskursus teologis. Namun mengingat gereja di Indonesia, khususnya gereja-gereja lokal, umumnya selalu bersinggungan dengan tradisi pemberian mas kawin yang merupakan bagian dari adat pernikahan, maka penting bagi teologi Kristen untuk memberikan jawaban 
atas pertanyaan apakah nilai mas kawin merendahkan atau mengagungkan calon mempelai wanita?

Jawaban atas pertanyaan ini dapat menjadi pintu masuk bagi gereja dalam menilai tradisi pemberian mas kawin, sejauh mana tradisi tersebut berkontribusi bagi pembangunan keluarga Kristen. Sebab sejumlah catatan menunjukkan pada batas tertentu tradisi ini membawa dampak negatif dalam pernikahan, khususnya terhadap para isteri. Salah satu contoh yang dapat dirujuk adalah hasil penelitian Divisi Perempuan dari Tim Relawan Untuk Kemanusiaan Flores (TRUK-F) Nusa Tenggara Timur (NTT) yang menyimpulkan bahwa belis (mas kawin) menjadi salah satu sumber kekerasan terhadap perempuan dalam rumah tangga di NTT. Di Kabupaten Sikka, pada tahun 2015 terdapat 5 orang korban yang disebabkan oleh belis, tahun 2012 ada 9 orang dan pada tahun 2013 sebanyak 11 orang. Kasus-kasus kekerasan disebabkan oleh sikap atau cara berpikir suami yang menganggap bahwa isteri adalah barang yang telah dilunasi dengan harga mahal, sehingga dia dapat melakukan apa saja terhadap istrinya tersebut.(Seba 2016).

Bangngu dalam penelitiannya terhadap sikap Gereja Kristen Sumba (GKS) Jemaat Kambaniru mengenai kenoto, pernikahan adat suku Sabu, menyimpulkan bahwa GKS sejauh ini memberikan dukungan kepada adat kenoto karena sejalan dengan nilai-nilai Kristen. Dukungan itu terlihat pada kehadiran para pelayan Tuhan dalam prosesi adat untuk membuka dan menutup kegiatan dengan doa.(Bangngu 2015) Meskipun 
demikian, tentu perlu kajian yang lebih mendalam mengenai masalah ini, terutama dalam mengaitkannya dengan nilai-nilai Kristen.

Tulisan ini bermaksud menguji nilai calon mempelai wanita dalam tradisi pemberian mas kawin suku Banggai dari sudut pandang ajaran Kristen. Ajaran tersebut sebaiknya yang menyangkut konsep tentang hakekat manusia sebagaimana dirancangkan dan ditetapkan Allah pada saat la menciptakannya. Manusia di sini adalah perempuan dan laki-laki. Konsep manusia dalam konteks penciptaan merupakan konsep yang asali (origin) di mana konsep-konsep selanjutnya akan merujuk kepada konsep ini. Sebab itu yang cocok adalah konsep manusia sebagai Imago Dei atau Gambar Allah sebagaimana tertulis dalam Kejadian 1:26-27.

Berfirmanlah Allah: "Baiklah Kita menjadikan manusia menurut gambar dan rupa Kita, supaya mereka berkuasa atas ikan-ikan di laut dan burung-burung di udara dan atas ternak dan atas seluruh bumi dan atas segala binatang melata yang merayap di bumi. Maka Allah menciptakan manusia itu menurut gambar-Nya, menurut gambar Allah diciptakan-Nya dia; laki-laki dan perempuan diciptakan-Nya mereka.

Konsep utama dari kedua ayat ini adalah manusia, laki-laki dan perempuan, diciptakan Allah sebagai Imago Dei, segambar dan serupa dengan Allah. Ratsara \& Bediako menyebutkan bahwa secara ontologis perempuan dan laki-laki adalah benar-benar setara.(Ratsara dan Bediako 2013)

Mangililo dalam uraiannya terhadap kedua ayat ini menyimpulkan bahwa makna Imago Dei yang ada di dalamnya adalah "manusia baik lakilaki maupun perempuan memiliki status dan posisi yang setara karena 
semuanya adalah serupa dengan Allah". Mangalilo mengutip Morschauser yang mengatakan bahwa manusia diciptakan paling akhir dalam urutan penciptaan sebagai laki-laki dan perempuan dalam gambar Allah dengan tujuan agar manusia dapat merepresentasikan, menjadi saksi dan melayani di bawah kekuasaan/pengawasan Allah. Mereka hanya berkata dan bertindak sesuai dengan tugas yang diberikan bagi mereka. Jadi, sebagai Imago Dei, manusia adalah "hamba yang setia," di mana kehidupan mereka terikat, dibatasi dan ditentukan oleh perkataan Allah semata. (Mangililo 2017). Dari pendapat Morschauser ini berarti dalam konsep manusia sebagai Imago Dei, posisi di atas dari segala ciptaan Allah lainnya. Mereka mencerminkan kemuliaan Allah dan tidak bisa disetarakan dengan ciptaan lainnya.

Terkait dengan tradisi pemberian mas kawin, ada dua pertanyaan yang bisa diajukan. Pertama, apakah nilai calon mempelai wanita dalam tradisi pemberian mas kawin mencerminkan kesetaraan perempuan dengan laki-laki sebagai sama-sama Imago Dei? Menurut Capaldi, kesetaraan merupakan sebuah konsep yang deskriptif maupun normatif. Secara deskriptif, kesetaraan merujuk pada suatu sifat hubungan antara berbagai entitas yang mendapatkan penghargaan yang serupa (identical respect) dalam hal-hal tertentu. Secara normatif, kesetaraan menunjuk pada suatu pengakuan bahwa semua manusia pada dasarnya adalah setara (dekriptif) namun setiap orang mendapatkan perlakuan khusus. Alasannya, secara faktual tidak ada dua entitas yang bisa mendapatkan 
penghargaan yang identik dalam segala hal. Jika itu terjadi maka keduanya bukan lagi dua entitas, melainkan satu. (Capaldi 2002). Perempuan dan laki-laki merupakan dua entitas yang berbeda. Namun dalam hal sebagai Imago Dei mereka mendapatkan penghargaan yang sama.

Pertanyaan kedua, apakah nilai calon mempelai wanita dalam tradisi pemberian mas kawin mencerminkan posisi perempuan sebagai hamba Allah yang berada di atas ciptaan lainnya? Perempuan sebagai hamba Allah setidaknya memiliki dua makna: 1) tidak bisa disetarakan dengan ciptaan lainnya, entah itu benda mati atau pun benda hidup, 2) hanya Allah sang pencipta yang memiliki otoritas untuk menentukan nilainya sebagai manusia, Gambar Allah.

Untuk menjawab kedua pertanyaan ini maka penulis melakukan kajian mengenai tradisi pemberian mas kawin secara khusus pada suku Banggai, salah satu suku di Indonesia, yang menempati wilayah bagian timur Propinsi Sulawesi Tengah (kabupaten Banggai, kabupaten Banggai Kepulauan, dan kabupaten Banggai Laut). Tradisi pemberian mas kawin di suku ini, secara umum, memiliki kesamaan dengan suku-suku lain di Indonesia. Ini tercermin dari hasil penelitian sebelumnya yang dilakukan Ladjahia di desa Kombutokan, kecamatan Totikum, kabupaten Banggai Kepulauan. Temuan Ladjahia antara lain: Pertama, bentuk mas kawin yang diminta pihak perempuan cenderung dalam bentuk uang. Kedua, mas kawin utama (sai batango) terutama digunakan untuk membiayai 
pesta pernikahan. Ketiga, penetapan jumlah mas kawin ditentukan oleh status sosial calon mempelai wanita. Jika status sosialnya tinggi, dan juga berpendidikan tinggi, jumlah mas kawinnya bisa sangat tinggi. Jumlah mas kawin yang tinggi dan pesta pernikahan yang meriah diyakini menaikkan prestise sosial keluarga. Keempat, penetapan jumlah mas kawin yang terlalu tinggi bagi ukuran kemampuan calon mempelai laki-laki dapat mengakibatkan batalnya rencana pernikahan. Ladjahia menganalisis tradisi ini dari perspektif hukum Islam dan melihat bahwa penetapan jumlah mas kawin yang tinggi dan mengakibatkan batalnya suatu pernikahan bertentangan dengan hukum Islam. (Ladjahia 2015).

Perbedaan penelitian ini dengan penelitian Ladjahia adalah: Pertama, penekanannya pada nilai calon mempelai wanita yang direpresentasikan oleh jumlah dan bentuk mas kawin. Kedua, ditinjau dari perspektif teologi Kristen. Secara spesifik, tujuan penelitian ini adalah mengkaji nilai calon mempelai wanita dalam tradisi pemberian mas kawin pada masyarakat suku Banggai dari konsep manusia sebagai Imago Dei dalam Kejadian 1:26-27.

\section{METODE PENELITIAN}

Metode yang digunakan dalam penelitian ini adalah studi pustaka. Metode ini, menurut Khatibah (2011), merupakan kegiatan mengumpulkan, mengolah, dan menyimpulkan data dengan menggunakan teknik tertentu guna mencari jawaban atas permasalahan yang hendak diteliti berdasarkan sumber data kepustakaan.(dalam Sari 
2020). Data dianalisis dengan tehnik yang dikemukakan Miles dan Huberman dalam metode kualitatif, yaitu reduksi data, display data, dan kesimpulan/verifikasi. Mereduksi data berarti merangkum, memilih hal-hal yang pokok, memfokuskan pada hal-hal yang penting, mencari tema dan polanya. Panduan yang digunakan dalam mereduksi data adalah tujuan penelitian. Hasil reduksi data akan disajikan (display) dalam bentuk uraian singkat, bagan, hubungan antar kategori, flowchart, dan sejenisnya. Langkah terakhir adalah penarikan kesimpulan dan verifikasi. Kesimpulan diambil dari data-data yang didisplay. Apabila-apabila data-data tersebut sudah valid maka kesimpulannya sudah dapat dianggap kredibel. (Sugiyono 2018).

\section{HASIL PENELITIAN}

Penelitian ini menemukan jawaban atas pertanyaan dua penelitian di atas yaitu: Pertama, apakah nilai calon mempelai wanita dalam tradisi pemberian mas kawin mencerminkan kesetaraan perempuan dengan lakilaki sebagai sama-sama Imago Dei? Kedua, apakah nilai calon mempelai wanita dalam tradisi pemberian mas kawin mencerminkan posisi perempuan sebagai hamba Allah yang berada di atas ciptaan lainnya?

Hasil penelitian atas kedua pertanyaan tersebut adalah: Pertama, nilai calon mempelai wanita dalam tradisi pemberian mas kawin suku Banggai tidak mencerminkan kesetaraan perempuan dengan laki-laki sebagai sama-sama Imago Dei. Kedua, nilai calon mempelai wanita dalam 
tradisi pemberian mas kawin suku Banggai tidak mencerminkan posisi perempuan sebagai hamba Allah yang berada di atas ciptaan lainnya.

\section{PEMBAHASAN}

Dalam pemberian mas kawin pada suku Banggai perempuan merupakan obyek yang ditentukan nilainya. Nilai mempelai perempuan ditentukan berdasarkan kesepakatan keluarga pihak laki-laki dan keluarga perempuan itu sendiri. Keluarga perempuan menentukan nilainya, Ialu pihak laki-laki menimbang. Jika ia merasa terlalu berat bisa menawar. Seperti dikemukakan Ladjahia, jika laki-laki merasa terlalu berat ia bisa mundur.

Proses ini menunjukkan bahwa mempelai perempuan tidak memiliki otonomi atas dirinya sendiri. Meskipun sebagian orang menganggap bahwa pemberian mas kawin bukanlah transaksi jual beli tapi dalam suku Banggai proses tersebut menunjukkan terjadinya komodifikasi perempuan. Komodifikasi, sederhananya seperti dikemukakan Fernandes, adalah proses pemberian nilai ekonomi kepada sesuatu yang sebelumnya berada di luar konsep ekonomi.(Fernandez 2013) Bagi keluarga kedua mempelai, mungkin saja penentuan nilai mas kawin bukan untuk "memperjualbelikan" calon mempelai wanita. Namun demikian, pemberian nilai terhadap calon mempelai wanita, apalagi dikonversi ke dalam nilai uang atau barang, telah menjadikan sang mempelai memiliki nilai ekonomi. 
Fernandez juga mengemukakan pengertian lain dari komodifikasi, yaitu proses di mana obyek material, jasa/pelayanan, dan ide menjadi komoditas yang diperjual-belikan dalam pasar. Komoditas sendiri nilai tukarnya (exchange value) lebih penting dibandingkan nilai gunanya (use value). Komodifikasi adalah proses mengubah nilai guna menjadi nilai tukar. Ketika konsumen modern membeli komoditas, ia tidak membayar untuk mendapatkan nilai gunanya tapi cenderung untuk mendapatkan nilai gengsi (prestige) yang dilekatkan masyarakat pada komoditas tersebut.(Fernandez 2013)

Ketika calon mempelai menjadi komoditas, yang dibayar oleh pihak laki-laki melalui mas kawin sesungguhnya adalah gengsi dari keluarga. Faktanya uang mas kawin umumnya digunakan untuk biaya pesta. Semakin besar pesta pernikahannya semakin naik prestise sosial keluarga.

Komodifikasi seperti ini menunjukkan suatu relasi kekuasaan di mana terdapat pihak yang inferior dan pihak yang superior. Perempuan berada di posisi inferior karena dia menjadi komoditas. Laki-laki berada di posisi superior. Benedicta dalam tulisannya tentang Dinamika Otonomi Tubuh Perempuan mengemukakan bahwa otonomi atas tubuh perempuan selalu berhubungan dengan kekuasaan. Seorang perempuan dikatakan memiliki otonomi atas tubuhnya sendiri jika ia dapat melakukan kontrol atas tubuhnya. Namun, tidak semua perempuan dapat memiliki otonomi atas tubuhnya sendiri. Ketidakmampuan 
perempuan dalam menentukan arah atas tubuhnya tersebut dapat dilihat ketika tubuh perempuan dijadikan komoditas oleh pihak lain untuk mendapatkan keuntungan bagi pihak tersebut. (Benedicta 2011)

Konsep ini jika dibandingkan dengan posisi perempuan dalam pemberian mas kawin menunjukkan bahwa perempuan tidak memiliki kontrol atas terhadap nilai yang dilekatkan pada dirinya. Nilai tersebut ditentukan oleh keluarganya sendiri dan pihak laki-laki. la menjadi sebuah komoditas untuk mencapai prestise laki-laki dan prestise keluarganya sebagai pemilik dirinya. Dengan begitu, dalam tradisi pernikahan suku Banggai, mas kawin bukanlah penghargaan kepada perempuan.

Keadaan ini tentu bertentangan dengan konsep manusia, laki-laki dan perempuan, sebagai imago Dei. Seperti dikatakan Mangililo bahwa keduanya setara karena sama-sama serupa dengan Allah. Setara artinya mendapatkan penghargaan yang sama (Mangililo 2017). Dalam hal pemberian mas kawin, perempuan ditempatkan sebagai obyek yang dikomodifikasi yang berarti nilainya dianggap lebih rendah dari laki-laki.

Hal kedua yang penting dalam konsep manusia sebagai Imago Dei adalah bahwa keduanya sama-sama sebagai hamba Allah yang setia, berada di bawah Allah, dan di atas makhluk lainnya. Artinya, baik perempuan maupun laki-laki tidak bisa disetarakan dengan makhluk lain, baik makhluk yang hidup maupun tidak hidup.

Namun dalam pemberian mas kawin pada suku Banggai, nilai mempelai wanita sebagai manusia dikonversi ke dalam sejumlah uang 
atau barang. Meskipun jumlah uang atau benda lain yang diberikan cukup atau sangat besar namun hal itu telah mereduksi nilai kemanusiaannya sebagai Imago Dei. Manusia, baik laki-laki maupun perempuan, tidak bisa disetarakan nilainya dengan benda.

Ketidaksetaraan posisi perempuan dan laki-laki dalam pernikahan merupakan ekspresi dari ideologi patriarki, sebuah ideologi yang menempatkan laki-laki (dewasa) di pusat kekuasaan, baik di rumah tangga maupun di wilayah publik.(Sakina dan A 2017; Nurmila 2015) Dalam analisisnya tentang perkawinan masyarakat Yahudi, Becher mengatakan pernikahan merupakan prakarsa laki-laki. Laki-laki yang mengambil perempuan dalam pernikahan. Sebelum menikah, seorang perempuan berada di bawah otoritas ayahnya, setelah menikah otoritas tersebut dipindahkan kepada suaminya. Pemberian uang merupakan penegasan secara simbolis tentang perubahan status seorang anak perempuan menjadi milik seorang laki-laki sebagai suaminya.(Becher 2001).

Dengan demikian, bisa dikatakan bahwa dukungan terhadap pemberian mas kawin dalam pernikahan merupakan dukungan terhadap budaya patriarki atau dukungan terhadap dominasi laki-laki dalam pernikahan. Seorang pendeta yang melayani di salah satu gereja di wilayah suku Banggai mengatakan bahwa sejauh ini gereja belum melihat pemberian mas kawin bertentangan dengan nilai-nilai Kristen. Para hamba Tuhan biasa memenuhi undangan keluarga untuk menghadiri acara 
penentuan dan pemberian mas kawin, meskipun peran yang dimainkan baru sebatas sebagai saksi, lalu membuka dan menutup acara dengan doa (Wawancara, 26 April 2020).

Di masa kini makna pemberian mas kawin sudah mulai bergeser di kalangan tertentu. Sebagian dari mereka menganggap mas kawin hanya kebiasaan saja sehingga diberikan secara simbolis saja. Aktor Indonesia, Fedi Nuril, ketika melangsungkan pernikahan memberi mas kawin 10 gram emas kepada isterinya yang menurutnya emas tersebut tidak memiliki makna khusus sama sekali. Menurut Fedi, mas kawin hanyalah simbol untuk melengkapi momen pernikahan karena yang penting adalah proses mengarungi bahtera rumah tangga.(Anggie 2016) Selain Fedi Nuril ada pasangan-pasangan lain yang memberi mas kawin hanya sebagai simbol belaka, bahkan terkesan aneh dan unik. Ada yang memberi kain kafan, secangkir kopi, segelas air putih, sandal jepit, knalpot motor, telur ayam, mengucapkan ikrar Sumpah Pemuda, dll. (Pasha 2019; Maskawin 2019)

Fakta ini menunjukkan bahwa pemaknaan terhadap nilai budaya yang terkandung dalam pemberian mas kawin akan terus mengalami pergeseran. Artinya, sebagai sebuah tradisi tentu bisa diubah. Bagaimana dengan gereja? Pada masyarakat suku Banggai, gereja biasanya melakukan pemberkatan nikah setelah prosesi adat telah dilampaui. Gereja menerima prosesi adat tersebut sebagai hal yang baik. Lalu bagaimana jika tradisi tersebut, khususnya bagian pemberian mas kawin, 
bertentangan dengan makna kesetaraan perempuan dan laki-laki sebagaimana tercantum dalam Kej. 1:26-27? Hal ini tentu perlu mendapatkan kajian yang serius guna mengoptimalkan upaya gereja menghadirkan keadilan di tengah-tengah kehidupan jemaat maupun masyarakat.

\section{KESIMPULAN}

Pemberian mas kawin pada suku Banggai tidak sejalan dengan nilai kesetaraan perempuan dan laki-laki menurut konsep manusia sebagai Imago Dei dalam Kejadian 1:26-27. Ini terjadi karena tradisi pernikahan masyarakat suku Banggai, seperti halnya tradisi pernikahan pada masyarakat lain pada umumnya, dihidupi oleh ideologi patriarki. Sebab itu gereja perlu mengkritisi tradisi tersebut guna mendukung pernikahan yang adil, bebas dari kekerasan, di tengah-tengah jemaat maupun masyarakat.

Penelitian ini perlu dilanjutkan dengan kajian terhadap strategi gereja yang efektif untuk mentransformasi nilai-nilai patriarki yang ada dalam tradisi pernikahan suku Banggai. Ini penting karena sejauh ini pihak gereja belum melihat secara kritis nilai ketidaksetaraan yang terkandung dalam tradisi pernikahan tersebut.

\section{DAFTAR ISI}

Aini, Noryamin. 2014. "Tradisi Mahar Di Ranah Lokalitas Umat Islam: Mahar Dan Struktur Sosial Di Masyarakat Muslim Indonesia." 
AHKAM : Jurnal IImu Syariah 17 https://doi.org/10.15408/ajis.v17i1.1239.

Alfida, Rida, dan Saiful Usman. 2016. "PENETAPAN MAHAR BAGI PEREMPUAN DI DESA KAMPUNG PAYA, KECAMATAN KLUET UTARA, KABUPATEN ACEH SELATAN." Jurnal Ilmiah Mahasiswa Pendidikan Kewarganegaraan Unsyiah 1 (1): 89-96.

Anggie, Hernowo. 2016. "Makna Mas Kawin 10 Gram Emas Fedi Nuril dan Vanny Widyasasti ." ShowBiz Liputan6.com. 2016. https://www.liputan6.com/showbiz/read/2414070/makna-mas-kawin10-gram-emas-fedi-nuril-dan-vanny-widyasasti.

Apriyanti, Apriyanti. 2017. "Historiografi Mahar dalam Pernikahan." An Nisa'a: Jurnal Kajian Gender dan Anak 12 (2): 163-78.

Bangngu, Romi Adi Kurnia. 2015. "Sikap GKS Jemaat Kambaniru Terhadap Makna Tradisi Kenoto Ditinjau dari Teori Mas Kawin." Fakultas Teologi Universitas Kristen Satya Wacana.

Basri, Halimah. 2017. "KONSEP MAHAR (MASKAWIN) DALAM TAFSIR KONTEMPORER." Al Daulah: Jurnal Hukum Pidana dan Ketatanegaraan 6 (2): 310-30. https://doi.org/10.24252/ad.v6i2.4885.

Becher, Jeanne. 2001. Perempuan, Agama, dan Seksualitas.: Studi tentang pengaruh berbagai ajaran agama terhadap perempuan. BPK Gunung Mulia.

Benedicta, Gabriella Devi. 2011. "Dinamika Otonomi Tubuh Perempuan: A ntara Kuasa dan Negosiasi atas Tubuh." MASYARAKAT: Jurnal Sosiologi 16 (2): 141-56.

Capaldi, Nicholas. 2002. "The Meaning of Equality." In Liberty and equality, diedit oleh Tibor R. Machan, 1-33. Stanford: Hoover Institution Press.

Fernandez, Primeiro Wahyubinatara. 2013. "Komodifikasi Perempuan dalam Iklan Televisi." Jurnal ILMU KOMUNIKASI 8 (1): 60-80. https://doi.org/10.24002/jik.v8i1.182.

Ladjahia, Sisnawati. 2015. "Analisis Hukum Islam Terhadap Tradisi Pasai Dalam Perkawinan Adat Suku Banggai: Studi Kasus Di Desa Kombutokan Kecamatan Totikum Kabupaten Banggai Kepulauan Propinsi Sulawesi Tengah." UIN Sunan Ampel Surabaya.

Mangililo, Ira D. 2017. "IMAGO DEI: Sebuah Upaya Membaca Alkitab Sebagai Perempuan Indonesia Dalam Konteks Perdagangan Orang di Nusa Tenggara Timur 1." Indonesian Journal of Theology 5 (2): 147-77.

Maskawin. 2019. "Maskawin, dari Agama, Budaya, sampai Pilihan Unik." JEO Kompas.com. 2019. https://jeo.kompas.com/maskawin-dari- 
agama-budaya-sampai-pilihan-unik.

Muh. Ali, Hasbi, dan Raihanah Azahari. 2013. "OBJEKTIF SYARIAH DALAM PEMBERIAN MAHAR." Jurnal Figh 10: 57-76.

Neonnub, Fransiska Idaroyani, dan Novi Triana Habsari. 2018. "Belis: Tradisi Perkawinan Masyarakat Insana Kabupaten Timor Tengah Utara (Kajian Historis dan Budaya Tahun 2000-2017)." AGASTYA: JURNAL SEJARAH DAN PEMBELAJARANNYA 8 (01): 107. https://doi.org/10.25273/ajsp.v8i01.2035.

Nurmila, Nina. 2015. "PENGARUH BUDAYA PATRIARKI TERHADAP PEMAHAMAN AGAMA DAN PEMBENTUKAN BUDAYA." KARSA: Jurnal Sosial dan Budaya Keislaman 23 (1): 1. https://doi.org/10.19105/karsa.v23i1.606.

Pasha, Aufi Ramadhania. 2019. "10 Mas Kawin Unik ini Sempat Viral di Indonesia ." Cermati.com. 2019. https://www.cermati.com/artikel/10mas-kawin-unik-ini-sempat-viral-di-indonesia.

Ratsara, Paul, dan Daniel Bediako. 2013. "Man and Woman in Genesis 1 3: Ontological Equality and Role Differentiation." In Theology of Ordination Study Committee.

Sakina, Ade Irma, dan Dessy Hasanah Siti A. 2017. "MENYOROTI BUDAYA PATRIARKI DI INDONESIA." SHARE: Social Work Journal $7(1): 71-80$.

Sari, Milya. 2020. "Penelitian Kepustakaan (Library Research) dalam Penelitian Pendidikan IPA." Natural Science: Jurnal Penelitian Bidang IPA dan Pendidikan IPA 6 (1): 41. https://doi.org/10.15548/NSC.V6l1.1555.

Seba, Roberto Octavianus Cornelis. 2016. "Kekerasan Terhadap Perempuan Bagian Dari Pergeseran Nilai Budaya Belis Di Flores Nusa Tenggara Timur." Universitas Terbuka.

Subhan. 2018. "Nalar Kesetaraan Mahar dalam Perspektif Syariah Islam." AT-TURAS: Jurnal Studi Keislaman 4 (1): 1-16. https://doi.org/10.33650/at-turas.v4i1.193.

Sugiyono. 2018. Metode Penelitian Kuantitatif, Kualitatif, dan R\&D. Bandung: Alfabeta.

Thome, Helmut. 2015. "Values, Sociology of." In International Encyclopedia of the Social \& Behavioral Sciences, 47-53. Elsevier. https://doi.org/10.1016/B978-0-08-097086-8.32167-5. 